\title{
VOWEL LENGTH AS AN ORDERING CONSTRAINT IN BADINI KURDISH BINOMIALS: A QUANTITATIVE ANALYSIS
}

\author{
SAAED A. SAAED \\ Dept. of English, College of Basic Education, University of Duhok, Kurdistan Region, Iraq
}

(Received: August 15, 2017; Accepted for Publication: November 14, 2017)

\begin{abstract}
Major studies on binomial order (Cooper and Ross, 1975; Wright et al. 2005; Benor and Levy, 2006; Lohmann 2011; Mollin, 2012; Saaed, 2013) commonly agree that vowel length has a key role in the linear ordering of words in binomial phrases. Therefore, vowel length has been regarded as one of the basic phonological constraints of binomial order. The current study examines the role of vowel length as an ordering constraint in binomial phrases in Badini Kurdish. It proposes the hypothesis that there is a preference in Badini Kurdish binomials to place the word containing the shorter vowel in the first position and the word containing the longer vowel in the second position. To confirm the productive existence of this pattern in Badini Kurdish binomials, the study employs a quantitative analysis approach which is generally regarded as the most up-to-date research methodology used in the relevant literature. After applying the quantitative analysis to a big number of Badini Kurdish binomials (263 pairs), the study has come up with the finding that there is an outstanding preference for the ordering pattern hypothesized in this study. It has also been found that this ordering preference is statistically highly significant. Thus, the study concludes that this finding proves that vowel length can be considered an ordering constraint in Badini Kurdish binomials where the preference is frequently given for placing the words with the shorter vowels in the first position. Finally, it has to be pointed out that this finding is compatible with similar studies on binomials in other languages.
\end{abstract}

KEYWORDS: Vowel Length, Binomial-ordering, Badini Kurdish Binomials, Linguistic Quantitative Analysis.

\section{INTRODUCTION}

$\mathbf{M}$ alkiel is the first linguist who employed the term binomial in linguistics. According to Malkiel, a binomial is a "sequence of two words pertaining to the same form-class, placed on an identical level of syntactic hierarchy, and ordinarily connected by some kind of lexical link" (1959: 113). More recent works have agreed with Malkiel's definition: Gustafsson states that "a binomial is a sequence of two words which belong to the same form-class and which are syntactically coordinated and semantically related" (1984: 123), and Bhatia confirms this as well by describing a binomial as "a sequence of two or more words or phrases belonging to the same grammatical category having some semantic relationship and joined by some syntactic device such as 'and' or 'or" (1993: 108).

In general, linguistic studies on binomials can be classified into two main types: studies that look at the linear word order preference in binomials and studies that look at the overall structure of the entire binomial phrase. The first type has been commonly referred to as studies on binomial order (Benor and Levy, 2006) while the second as studies on binomial formation (Benor and Levy, 2006; Mollin, 2012) or binomial construction (Masini, 2006). The current research is concerned with the first type of studies as it is an attempt to describe one of the phonological factors that may have a role to play in linear word order in binomials in Kurdish language, particularly in Badini Kurdish (BK).

As its title suggests, studies on binomial order aim at finding the rules (or constraints) that determine linear word order on binomials. The relevant literature (e.g., Abraham, 1950; Malkiel, 1959; Cooper and Ross, 1975; Benor and Levy, 2006) indicates that many such studies exist and that their findings verify the existence of both linguistic and non-linguistic constraints to govern binomial order. The linguistic constraints are of 
various types; the phonological type is one of them. One of the basic phonological constraints found to be highly active in binomial order is vowel length (see section 2 for details). The present study describes the role of vowel length in binomial order in BK binomials; it carefully examines the importance, activity and statistical significance this phonological constraint may have in BK binomials. This is based on a quantitative analysis of a huge number of data examined in the present study.

The structure of this research paper is as follows: Section 2 reviews the literature. Section 3 briefly describes the variety of the Kurdish language investigated in this work. While section 4 states the research questions posed in this study, section 5 presents the proposed research hypothesis. Section 6 spells out the research methodology adopted in this study. Section 7 reports the findings of the study and section 8 concludes the study.

\section{LITERATURE REVIEW}

Previous studies on binomial order agree that phonology has a central role to play in the process of linear ordering in binomial phrases. In the relevant literature there have been many attempts to discuss the phonological constraints that determine binomial order. To introduce a comprehensive account of the subject, we will first look at all the phonological constraints presented in the relevant literature and then specify our review to the vowel length constraint which is the main focus of the current research paper.

\subsection{THE PHONOLOGICAL CONSTRAINTS}

Previous studies strongly indicate that phonology has a big role to play in binomial order. Almost all relevant studies hypothesize phonological constraints of binomial order. In this section we will consider all the phonological constraints proposed in the literature.

To begin with, let us look at the account made by Jespersen (1905), who, as reported by Abraham (1950: 279), believed that binomial order in English could be largely determined by rhythm. Here is the explanation offered by Jespersen:

In combinations of a monosyllable and a disyllable by means of and, the practice is always to place the short word first because the rhythm then becomes the regular 'aa 'aa instead of 'aaa 'a ( before the a denotes the strongly stressed syllable). Thus we say bread and butter, not butter and bread; further bread and water, milk and water, cup and saucer, wind and weather, head and shoulders, by fits and snatches, from top to bottom, rough and ready, rough and tumble, free and easy, dark and dreary, high and mighty, up and doing ... .

As a matter of fact, it is this phonological explanation that forms the basis of one of the main phonological constraints applied by subsequent researchers in this field. This will be evident in the course of this review as we shall pass through several studies making use of the same constraint.

Another linguist who tried to deal with binomial order phonologically was Behaghel (1909) as mentioned in Abraham (1950: 283). Behaghel, who worked on German binomials, reiterated Jespersen's theory, adding another phonetic rule to the effect that binomials with words containing accented $i$ or $u$ precede those with accented $a$. Applying this rule to Spanish binomials, Abraham observed that this rule could account for a few cases. But he also found that there are other cases in Spanish where $a$ precedes $i$ or $u$. Once again, there were many exceptions to this rule and, therefore, the search continued for a better account.

Contrary to Jespersen's rhythm theory, Scott (1913), as reported in Abraham (1950), examined two hundred seventy-six English binomials chosen at random and found that in forty-two percent of his cases the longer word preceded the shorter. The following are some of his examples:

1. butter and eggs

chapter and verse summer and fall profit and loss

Although Scott was correct in showing such counter examples to the rhythm theory suggested by Jespersen, he offered no theory of his own as a substitute to explain order preference in binomials.

Morawski (1927) was the next scholar who developed another phonological theory of binomial order. As mentioned in Abraham (1950), he suggested a number of further phonological rules to determine the order of rhymed words of equal syllabic length. These are the rules he proposed (cited in Abraham 1950: 281): 
1- Words beginning with a vowel or $h$ precede those beginning with a consonant.

2- In the case of words of equal length or nearly equal length both beginning with a consonant, the voiceless precede the voiced, the palatal the dental, and the dental precedes the labial.

3- Of the three labials $f, m$ and $p, f$ precedes $p$ and $f$ and $p$ precede $m$.

These rules, as shown by Abraham, fitted only the cases of rhymed binomials, and could not account for the unrhymed ones. Although Morawski claimed he could hardly find counter examples to his rules, Abraham (p.282) stated many exceptions which invalidate them. For example, the rules could not account for binomials in which the two words begin with vowel sounds. This is why Abraham thought that these rules could not cover all binomials and many of them were, therefore, left unclassified.

In his study, Malkiel (1959) mentioned what he called orchestration. Looking at examples such as those in (2), he asserted that rhyme and alliteration play a major supporting role which produces "a powerful welding effect on the whole" (p.122):

2. heckle and jeckle

by hook or (by) crook

to toil and moil

rough-and-tough (speech)

Apart from rhyme, he referred to other such welding supporting effects as: first, instances of assonance as in:

3. hit or miss

rise and shine

second, some other examples showing “...significant coincidence between concluding segments smaller than required for a rhyme, e.g. single consonants and consonant clusters" (p.122):

4. east and west

north and south

first and last

good and bad

and third, instances of what Malkiel called imperfect rhymes involving one accented and one unaccented vowel:

5. male and female

man and woman
The other effective factor he mentioned as being widespread is alliteration which refers to the repetition of initial consonants:

6. bed and board

big and black

birds and bees

deaf and dumb

dust and dirt

Moreover, Malkiel showed the role that morphology might play in binomial order when he mentioned morpheme repetition. The following are some of his examples in this regard:

7. obverse and reverse

sooner or later

upwards and downwards

In addition, he also touched upon cases where these factors might interact with each other. For example, he found that alliteration and echoing of the word final segment may work jointly as in:

8. tit or tat

to meddle and muddle

He also noticed that this effect might be doubled if a certain morpheme is being repeated as well:

9. bigger and better

farther and faster

Furthermore, he pointed out that "the repetition of a final morpheme easily coincides with rhyme" (p.124):

10. hither and thither highways and byways

Having introduced these examples, we can point out that Malkiel treated rhyme and alliteration, on the phonological level, and parallelism, on the morphological level under the rubric of orchestration, showing that "....all three tend to support one another and separately or jointly serve to underpin binomials" (p.125). But we may, quite reasonably, note that the abovementioned points made by Malkiel cannot explain why the first item in a binomial is given a preference over the second one. In fact, this observation is quite right as Malkiel's orchestration account was not given as an explanation of order preference of the first word over the second in a binomial but rather as an explanation of binomial formation as a whole. 
As for his account of sequential order preference, Malkiel set a number of phonological factors that may have a role to play in binomial order. He summarized these factors saying that they are "...describable by the qualitative and quantitative distribution of sounds, accentual and tonal schemas, total length of segments (with separate attention to the number of syllables, to the number of phonemes, and to the phonetic duration)" (p.149). In this connection, the operative phonological tendency that he observed was this: "Modern English displays a very marked partiality to short plus long: either monosyllable plus (normally paroxytonic) disyllable or two monosyllables of unequal size; rarely a mono- or di-syllable plus a polysyllable" (p.149). Here are some of the examples he gave to show this shortbefore-long ordering preference:

11. big and little

death and destruction

fame and fortune

far and away

salt and pepper

We should not forget that this finding is the same as that made previously by Jespersen (1905) as we mentioned earlier. But Malkiel also noticed that exceptions to this phonological constraint do exist and he gave some instances such as these in (12):

12. chapter and verse

classes and masses

a gentleman and a scholar

hither and yon

salaries and wages

However, we should also note here that this finding is not new for Malkiel as it was made earlier by Scott (1913) as mentioned above. Malkiel's contribution in this regard is probably his statement that such exceptional cases do not "...exceed $10 \%$ and can almost invariably be accounted for by powerful constellations of special circumstances inimical to this deep-rooted predilection" (Malkiel, 1959: 150). In addition, it is worth mentioning that he also observed that the same tendency is operative in various other languages such as German, French, Spanish, Portuguese, Russian, and Polish.

The next scholar who dealt with binomial order phonologically is Bolinger (1962). In this paper, Bolinger tried to answer some questions asked by
Malkiel (1959) who posed two specific phonological questions. After noting that "[m]odern English displays a very marked partiality to short plus long: either monosyllable plus (normally paroxytonic) disyllable, or two monosyllables of unequal size", Malkiel went on to ask, apropos of bright and shiny with five phonemes each, "[d]oes the fact that the latter [the word "shiny"] spreads them over two syllables recommend it for the position of $\mathrm{B}$ [second member]?". The second question was asked with reference to cases like pots and pans: "[w]here the number of the phonemes is equal, does the phonetic duration of contrastable sounds merit separate consideration?" (p.149). Trying to address these questions, Bolinger (1962) offered evidence that the answer to both questions was yes.

With these questions in mind, Bolinger gave a phonological account of binomial order. He noted that prominence could be regarded as an important factor responsible for the binomial order due to the fact that the most convenient arrangement of syllables and, therefore, of the words containing them "is one in which those to be made prominent alternate with those to be kept subdued" (p.129). After classifying and inspecting a number of English binomials, he pointed out that when we order elements in binomials, "we look for the following three things: the accented syllable flanked by unaccentable ones; the accented syllable open and sonorous; the accented syllable in terminal position (p. 131). In addition to showing how these points were effective in binomial order, Bolinger supported his explanation by running three preference tests the results of which were all positive. In the end of his study, Bolinger concluded that such a preference for the above-mentioned phonological features in binomial order may result from the fact that they "make speech more intelligible" (p.138). Unlike his phonological account, which has been tested experimentally, Bolinger's statement that the phonological features regulating binomial order make speech more intelligible could have been discussed further and experimentally verified as well.

Up to this point, we have introduced the main phonological arguments on binomial order in the 1950s and 1960s. We would like to draw attention to the fact that although different scholars approached the subject phonologically, they 
focused on more or less similar points such as rhythm and the number of syllables that each word has. Nothing or very little was said about other phonological features such as vowel length, vowel quality, consonant sonority and consonant clusters. These features were described in detail by Cooper and Ross (1975) which is our next stop.

As a matter of fact, the study of Cooper and Ross is one of the comprehensive works in the field of binomials. Dealing with binomial order both phonologically and semantically, Cooper and Ross presented one of the detailed studies of expressions characterized by a frozen word order. In this section, we will introduce their phonological account only as it is the main focus of the present research.

Phonological constraints in binomial order have received a comprehensive investigation by Cooper and Ross (1975) and, later on, by Ross (1982). In their co-authored study, Cooper and Ross proposed seven phonological principles that, taken together, can account for the great majority of English binomials as they assume. These rules are reproduced in (13):

13. Compared to place 1 elements, place 2 elements contain, other factors being equal:

1. More syllables [P (Pänini's law)]

2. Longer resonant nuclei [V]

3. More initial consonants [Ci\#]

4. A more obstruent initial segment, if both place

1 and place 2 elements start with only one consonant [Ci]

5. A vowel containing a lower second formant frequency [F2]

6. Fewer final consonants [Cf\#]

7. A less obstruent final segment, if both place 1 and place 2 elements end in a single consonant [Cf]

(Cooper and Ross, 1975: 71)

In most cases, they based the above principles on examples made up of conjoined elements which differ minimally in the segment under investigation, i.e. examples that are minimal pairs, to use a phonological term. However, there exist no minimal pairs for some rules and in such cases the validity of the principle in question is based on examples which are non-minimal pairs but nevertheless suggestive. Supportive examples given by Cooper and Ross of each of the constraints stated above appear in (14) respectively:

14. a- vim and vigor; hot and heavy; hale and hearty; wild and wooly; rough and ready.

b- stress and strain; trick or treat.

c- fair and square; sink and swim; make or break; helter-skelter.

d- wear and tear; walkie-talkie; razzle-dazzle; wheel and deal.

e- this and that; one or two; man and boy; fiddlefaddle; criss-cross.

f- sink or swim; betwixt and between; wax and wane.

g- kith and kin; push and pull; thick and thin; hit or miss; safe and sane.

The first thing to note is that Cooper and Ross's phonological account is more detailed than those of their predecessors. Thus, unlike their predecessors' attempts, their attempt is not restricted to the description of the syllable structure in terms of quantity or quality. They rather suggest dealing with matters that were newly tackled in the investigation of binomial order at that time such as vowel length, sonority of both initial and final segments, and consonant cluster.

Since the publication of Cooper and Ross's paper, the constraints which they put forward have been the subject of further analysis in several subsequent works. Let us begin with Cutler andCooper (1978) who carried out "a phonememonitoring experiment" to indicate that the phonemes are recognized more quickly in the sequence "monosyllabic before bisyllabic" than in the reverse order. Also, they argued that the vowel of the first word is actually higher than that of the second word. This means that it is a vowel with a lower first formant, not second as suggested by Cooper and Ross.

Also interested in a further investigation of Cooper and Ross's constraints were a couple of psycholinguists, Pinker andBirdsong (1979), who ran a number of experiments aiming at checking the "speaker's sensitivity to rules of frozen word order" which is the title of their research. After examining the phonological rules proposed by Cooper and Ross experimentally, they concluded that "rules of frozen word order are psychologically real".

Oden and Lopes (1981) also performed experimentally based research on the same topic but their aim was to account for how these rules operate in combination. They concluded that when different rules are combined in determining the frozen order, "it does not appear that the effects 
produced by these rules can be compounded independently" (p.678). Thus, constraint interaction was another point that raised the need for further research.

Ross (1982), this time working on his own, introduced another investigation basically related to the phonological rules alone. Based on examining some more data, he suggested a number of modifications. These were associated with two rules: F2 and Cf\#. In another study, Oakeshott-Taylor (1984) examined experimentally the role of just one of the rules mentioned in Cooper and Ross. In particular, this study was restricted to investigating "the identity of the vowels in conjoined CVC syllables" (p.236). It concluded that the quality of the vowel is an important factor in determining BO.

In studies confined to the question of why in paired popular names (e.g. Fred and Wilma, Barney and Betty, Sonny and Cher) the male name tends to precede the female name in English, Wright andHay (2002) and Wright et al., (2005) studied linear order in popular names in American English applying, among other rules, the phonological constraints proposed by Cooper and Ross. They found that compared with the female name, the male name tends to contain more of the phonological features that give them preference to take up the first position.

Finally, it has to be pointed out that the recent studies pertaining to binomial order adopted the same constraints suggested by Cooper and Ross (1975). Benor and Levy (2006) is considered one of the most inclusive recent accounts of not only phonological constraints but of all the remaining types of constraints. This study is remarkable mainly because the authors adopted ordering constraints already posed in the literature and made good use of potential linguistic findings that have come to light since then. Thus, while it is true that they followed all the phonological constraints proposed by Cooper and Ross in their analysis, they contributed to this field by offering phonological justifications for the constraints and by proposing some further phonological constraints such as those relevant to stress, syllable weight and syllable openness. To conclude this section, it should be emphasized that the same phonological account suggested in Cooper and Ross and improved by Benor and Levy is followed by the most up-to-date studies on binomial order (e.g. Lohmann, 2011and2012; Mollin, 2012).

\subsection{THE VOWEL LENGTH CONSTRAINT}

Now that we have finished reviewing the phonological constraints on binomial order, we may narrow down our discussion to consider the phonological constraint which is the central focus of the current study. As we have introduced in the above review, Cooper and Ross (1975) suggested a set of seven phonological constraints that determine binomial order in English. Vowel length is one of the constraints that they suggested and explained as follows: the word containing the shorter vowel tends to occur in the first position while the word containing the longer vowel tends to occur in the second position in the same binomial phrase in English. Here are some of the examples they give:

15. stress and strain

trick or treat

hem and haw

The existence of the same constraint was confirmed by many subsequent scholars. In a different research paper in which he worked independently, Ross (1982: 276) specified the first position of English binomials for a "short monophthong" and the second position for a "long vowel or diphthong". Oakeshott-Taylor (1984) carried out a number of experiments to investigate the phonological constraints which are influential in binomial order and found that vowel length is an important factor in English where the second position tends to be taken by the word with the longer vowel. The more recent works on binomial order in English have also found an outstanding preference for the second position to have a longer vowel: Wright et al. (2005), Benor and Levy (2006), Lohmann (2011) and Mollin (2012) have asserted the remarkable preference for $\mathrm{B}$ to have a longer vowel.

If we look at relevant studies of binomial order in languages other than English, we can find that there are some studies which concern binomial order in both Arabic and Kurdish languages. Saaed (1997) presented a detailed investigation of binomial order in Iraqi Arabic and Saaed (2013) worked on a detailed investigation of binomial order in Standard Arabic. The productive existence of the vowel length constraint has been confirmed for Arabic binomials in both of these studies. Binomials in Kurdish have also been the subject of few studies recently: Hamasoor (2007), Jameel (2013) and Saaed andSimo (2016). Hamasoor's work is not related to binomial order 
since it is mainly concerned with the classification of Kurdish binomials into their syntactic parts of speech. Although Jameel (2013) is a study of binomial order in Kurdish, it is limited to the investigation of the semantic and pragmatic constraints of ordering only. Saaed andSimo (2016) is a study which focuses mainly on the effect of the phonological constraint of syllable count on Kurdish binomials. Therefore, the present study is a pioneering work aiming at contributing to the field of binomial order studies in BK by investigating the role of vowel length in the process of linear ordering in Kurdish binomials.

\section{KURDISH VARIETY}

The variety of the Kurdish language studied in this research is Kurmanji which is also called Badini Kurdish (henceforth BK) in Iraq. Kurdish is a language that belongs to the Indo-Iranian branch of the Indo-European family of languages. Although it contains a number of varieties, it is generally agreed upon among linguists that Kurmanji and Sorani are the most outstanding Kurdish varieties (Gerard and Daniel, 1998; Thackston, 2006). Among these two dialects, Kurmanji is the more frequently used one since it is the dialect used by the largest number of Kurds (cf Kurdish Academy of Language's, 1992).

\section{RESEARCH QUESTIONS}

The primary aim of the present research is to answer the following questions: Is the vowel length ordering constraint active in binomials in $\mathrm{BK}$ ? If the answer is found to be yes, then the second research question would be to double check if this activity is so productive that it is statistically significant and that it is not just a matter of chance.

\section{RESEARCH HYPOTHESES}

To answer the abovementioned questions convincingly, we propose to check out the following hypothesis in our data: The word with the shorter vowel precedes the word with the longer vowel in the same binomial phrase.

\section{RESEARCH METHODOLOGY 6.1 DATA}

The data studied in the current work are the binomial phrases which are characterized with a high frequency of occurrence in BK. They are completely based on the data analyzed in the recent research of Saaed and Simo (2016). The total number of binomials is 263 pairs. They have all been written in Latin orthography, phonemically transcribed and then reviewed by some colleagues specialized in BK.

\subsection{METHODOLOGY}

Recent studies on binomial order constraints ((Benor and Levy, 2006; Lohmann, 2011; Mollin, 2012; Saaed, 2013; Saaed and Simo, 2016) apply a special kind of a statistical quantitative analysis as the main research methodology in their works. The main reason is that this type of analysis enables the researcher to double check the actual existence of the ordering constraint under investigation and to make sure that the constraint is statistically active and productive, and does not just exist as a matter of chance. Previous studies concerned with binomial order were subjective in their judgment as they were based on mere observations. Therefore, some of them were really doubtful about the actual productivity of their results. Thus, Cooper and Ross (1975: 79) were among the first scholars who raised the need for a statistical quantitative analysis of binomial order:

Since such [their] data consist of non-minimal pairs, however, strong support can only be provided by sampling a very large number of such pairs and stating the statistical probabilities of a phonological regularity of interest, regarding other phonological factors as undesirable "noise" in the data. Since English contains very few minimal pairs with which to test certain regularities, it appears necessary to resort to such statistical sampling procedures in the future if we hope to be able to state with any degree of certainty the existence of certain regularities, and, of at least equal importance, the relative strengths of these regularities.

Two basic quantitative measurements are employed in this type of analysis. The first one measures the activity of the constraint under investigation. This is achieved by calculating the satisfaction rate of the constraint in the data. While the second one measures the productivity of the activity of the constraint under investigation. This is achieved by considering the statistical significance of the constraint under investigation. The results of these calculations are shown by reporting the alignment trends of the constraint in terms of the proportion $\pi$ active of the binomials active for the constraint under investigation and which are aligned with the constraint; $p$-values for these proportions are derived from the null hypothesis of the binomial distribution with parameter $1 / 2$. These statistical measurements 
have been made using the SPSS (Statistical Package for the Social Sciences).

\subsection{CODING}

In coding for vowel length in the data analyzed in the current study, the following Phonemic length division, suggested in Hasan (2012), has been depended on:

a) Short vowels: i, u , o , a

b) Long vowels: i: , e: , a:

\section{FINDINS}

In this section we report the findings of the study. We will start first by recalling the hypothesis proposed in the current study: the word with the shorter vowel precedes the word with the longer vowel in the same binomial phrase. Figures 1 and 2 show the satisfaction rates in the binomials analyzed in our data:
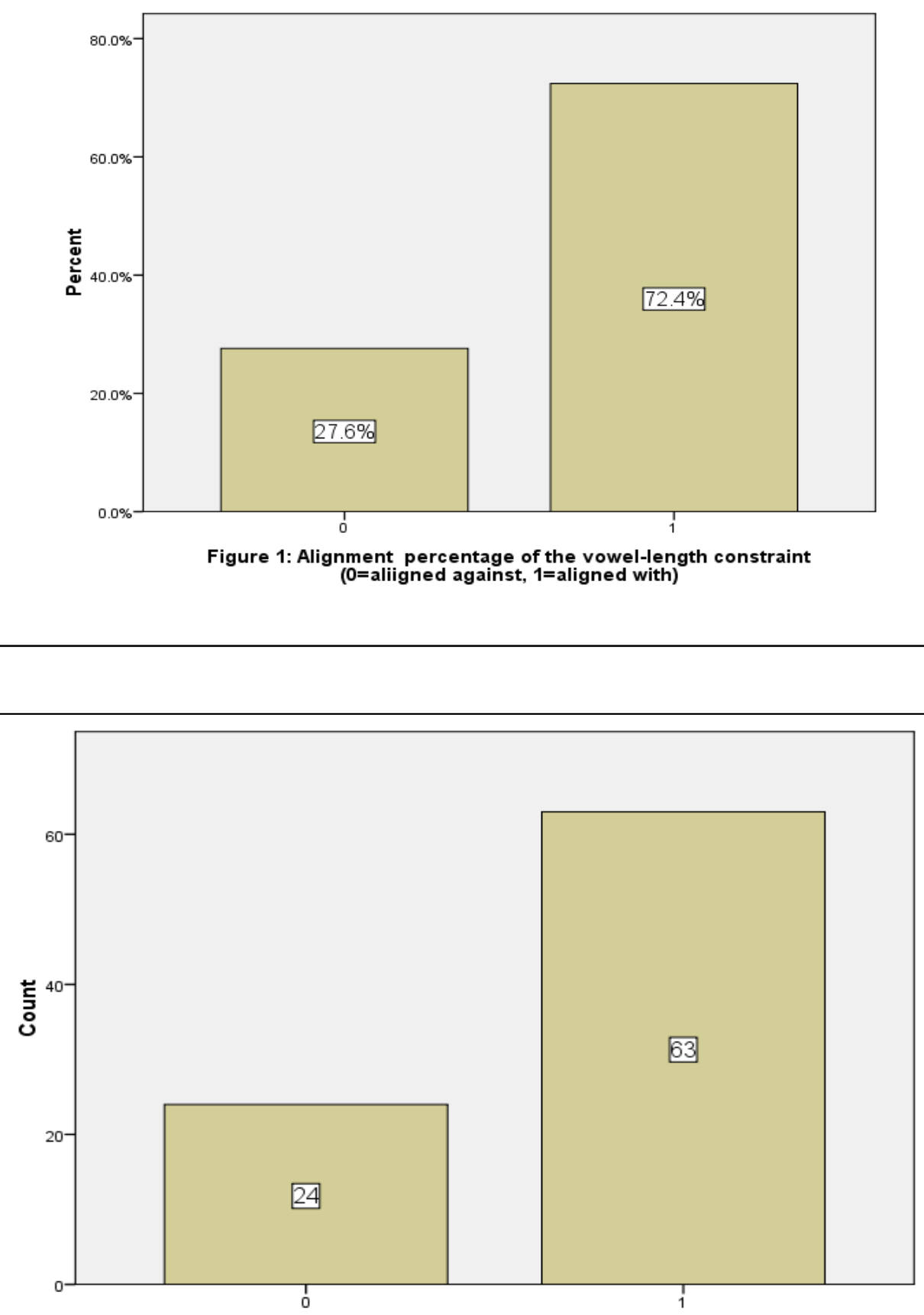

Figure 2: Alignment counts of the vowel-length constraint $(0=$ aligned against, $1=$ aligned with) 
As can be seen in the abovementioned figures, there is an outstandingly frequent pattern in the binomials in our data to have the word with the shorter vowel in the first position and the word with the longer vowel in the second position. This finding can be expressed statistically by saying that the number of binomials which are aligned with the ordering constraint hypothesized in the 16. ser u çav/sar u tfa:v/ 'head and eye' jin u mêr / zin u me:r/ 'wife and husband' reş u spî / ra u spi:/ 'black and white' dev u lêv / dav u le:v/ 'mouth and lip' şeş $u$ bêş / $\int \mathrm{a} \int \mathrm{u}$ be: $\mathrm{J} /$ 'six and five' sist u xar / sist u xa:r/ 'unstick and askew' çep u rast /ffap u ra:st/ 'left and write' kevn u nwî / kafn u nwi:/ 'old and new' dil u can / dil u dza:n/ 'heart and soul' current study is obviously higher than the number of cases aligned against the hypothesis. Therefore, this finding provides clear evidence that there is a prominent tendency in BK binomials studied in this research towards satisfying the ordering constraint hypothesized in the current study. The list mentioned in (2) below are some of the supportive examples found in our data:

xeml u xêl / xaml u xe:1/ 'ornamenting and scarf'

All the pairs in (2) and many more in our data evidently demonstrate the existence of a frequently occurring tendency in BK binomial phrases to have the longer vowel in the second rather than the first position. In order to confirm that this tendency stands for a predominant regularity in BK binomials, let us consider some further statistical details shown in figure 1 :

Table (1):- Binomial test of the vowel-length constraint

\begin{tabular}{lllllll}
\hline & & Category & $\mathrm{N}$ & $\begin{array}{l}\text { Observed } \\
\text { Prop. }\end{array}$ & Test Prop. & $\begin{array}{l}\text { Asymp. Sig. } \\
\text { (2-tailed) }\end{array}$ \\
\hline \multirow{2}{*}{ vowel_length } & Group 1 & 1.00 & 63 & .72 & .50 & $.000^{\mathrm{a}}$ \\
\cline { 2 - 7 } & Group 2 & .00 & 24 & .28 & & \\
\cline { 2 - 7 } & Total & & 87 & 1.00 & & \\
\hline a. Based on Z Approximation. & & & & \\
\hline
\end{tabular}

Table 1 gives the number of the binomials that agree (statistically speaking align with) the hypothesis proposed in the current study as well as the number of the binomials that do not agree (align against) the hypothesis. First of all, let us start with the total number of cases where the ordering constraint hypothesized in this work is found to be involved (active). The total number is 87 binomial pairs. Out of these, 63 binomials (or $72 \%$ ) are aligned with the constraint whereas 24 binomials (or 28\%) are aligned against it. Table 1 also shows that the satisfaction rate of the binomials aligning with the constraint is highly significant $(\mathrm{p}<.001)$. Achieving a satisfaction rate which is statistically highly significant evidently indicates the vowel length factor is one of the phonological factors which is regularly active and productive in the ordering of binomials in BK. Accordingly, this finding strongly confirms the hypothesis proposed in the current study that there is a tendency to place words of shorter vowels in the first position in BK binomials. In addition, the finding is in line with the relevant research in the literature which confirms the existence of the same constraint for binomials in English and some other languages (see section 2).

\section{CONCLUSION}

The conclusion of the present study can be drawn by restating the research questions asked back in section 4 and answering them. The first question: (1) Is the vowel length ordering constraint active in binomials in BK? Based on the finding explained in the section 7 , the answer is that the vowel length ordering constraint is an active constraint in the binomials in our data. The second question: (2) If the answer is found to be yes, then the second research question would be to double check if this activity is so productive that it is statistically significant and that it is not just a matter of chance. Based on the finding explained in the section 7, the answer to the second question is that the activity of the vowel length ordering constraint is statistically highly significant $(\mathrm{p}$ $<.001)$. 
The present research therefore concludes that there is statistical evidence on the real existence of the vowel length ordering constraint in BK binomials.

\section{Bibliography}

Abraham, R. D. (1950). Fixed order of coordinates: A study in comparative lexicography. Modern Language Journal , 34, pp. 276-287.

Behaghel, O. (1909). Beziehungen zwischen umfang und reihenfolge von satzgliedern. Indogermanische Forschungen , 25, pp. 110142.

Benor, S. B., \& Levy, R. (2006). The chicken or the egg? A probabilistic analysis of English binomials. Language, pp. 233-278.

Bhatia, V. K. (1993). Analysing genre: Language use in professional settings. London: Longman.

Bolinger, D. L. (1962). Binomials and pitch accent. Lingua, 11, pp. 34-44.

Cooper, W., \& Ross, J. (1975). World order. In R. E. Grossman, L. J. San, \& J. J. Vance (Eds.), Papers from the parasession on functionalism (pp. 63-111). Chicago: Chicago Linguistic Society.

Cutler, A., \& Cooper, W. E. (1978). Phonememonitoring in the context of different phonetic sequences. Journal of Phonetics, 6, pp. 221225.

Gerard, G., \& Daniel, M. (1998). Preliminary Reflection of the Constitution of a National Corpus of Kurdish Language. Retrieved 112 , 2016, from http:/ggautierk.free.fre/1project.htm/

Gustafsson, M. (1984). The syntactic features of binomial expressions in legal English. Text , 4, pp. 123-142.

Hamasoor, S. (2007). A syntactic and semantic study of collocation in English and Kurdish. Unpublished MA thesis: University of Suleimaniya.

Hasan, A. M. (2012). Kurdish Intonation with Reference to English. Unpublished $\mathrm{PhD}$ thesis: University of Ulster, UK. .

Jameel, H. K. (2013). Binomials in English and Kurdish: A contrastive study. Unpublished MA thesis: University of Duhok.

Jespersen, O. (1905). Growth and structure of the English language. Leipzig: B. G. Teubner.

Kurdish, A. o. (1992). Retrieved 1 12, 2016, from Kurdish Academy of Language: http://www.kurdishacademy.org/
Lohmann, A. (2011). Beyond irreversible binomials $-a$ processing view on constituent order in coordinate constructions. $\mathrm{PhD}$ thesis: University of Hamburg.

Malkiel, Y. (1959). Studies in irreversible binomials. Lingua , 8, pp. 113-160.

Masini, F. (2006). Binomial constructions: Inheritance, specification and subregularities. Lingue $e$ Linguaggio , 5 (2), pp. 207-232.

Mollin, S. (2012). Revisiting binomial order in English: Ordering constraints and reversibility. English Language and Linguistics , 16 (1), pp. 81-103.

Morawski, J. (1927). Les formules rimees de la langue Espagnole. Revista de Filologia Espanalo , XIV, pp. 113-133.

Oakeshott-Taylor, J. (1984). Phonetic factors in word order. Phonetica , 41 (4), pp. 226-237.

Oden, G. C., \& Lopes, L. L. (1981). Preference for order in freezes. Linguistic Inquiry, 12 (4), pp. 673-679.

Pinker, S., \& Birdsong, D. (1979). Speakers' sensitivity to rules of frozen word order. Journal of Verbal Learning and Verbal Behavior, 18, pp. 497508.

Ross, J. R. (1982). The sound of meaning. In T. L. Korea (Ed.), Linguistics in the morning calm (pp. 275-290). Seoul: Hanshing Publishing.

Saaed, S. (1997). Binomial expressions in Iraqi Arabic with reference to English: A phonopragmatic approach. Unpublished M.A. thesis: University of Mosul.

Saaed, S. (2013). Binomials in Modren Standard Arabic with Reference to English: An investigation of ordering constraints. Unpublished $\mathrm{PhD}$ thesis: University of Essex, UK.

Saaed, S., \& Simo, H. (forthcoming 2016). The shortbefore-long preference tendency as an ordering constraint in Badini Kurdish binomials: A quantitative analysis. The journal of the University of Duhok.

Thackston, W. M. (2006). Kurmanji Kurdish: A reference grammar with selected readings. Retrieved 1 12, 2016, from http: //www.fas.harvard.edu/Iranian/kurmanji/kurman ji-complete.pdf/.

Wright, S. K., Hay, J., \& Bent, T. (2005). Ladies first? Phonology,frequency, and the naming conspiracy. Linguistics , 43 (3), pp. 531-561.

Wright, S., \& Hay, J. (2002). Fred and Wilma: A phonological conspiracy. In S. Benor, M. Rose, D. Sharma, J. Sweetland, \& Q. Zhang (Eds.), Gendered practices in language (pp. 175-191). Stanford, CA: CSLI Publications 


\section{Appendix}

\begin{tabular}{|c|c|c|c|c|}
\hline $\begin{array}{l}\text { Idiomatic } \\
\text { Translation }\end{array}$ & Literal Translation & Latin & Kurdish Binominals & No. \\
\hline $\begin{array}{l}\text { Sense of } \\
\text { Thankfulness }\end{array}$ & Head and eye & ser u çav & لـاسمر و :جاةً & 1 \\
\hline \multirow[t]{2}{*}{$\begin{array}{l}\text { All sides } \\
\text { (All details) }\end{array}$} & Top and bottom & ser u bin & لــهةر و بن & 2 \\
\hline & Head and foot & ser u pê & لـسهر و بيى & 3 \\
\hline $\begin{array}{l}\text { Outward } \\
\text { (Appearance) }\end{array}$ & Head and front & ser u ber & [ـ[سهر و بلهر & 4 \\
\hline \multirow[t]{4}{*}{ Dependency } & Hand and foot & dest u pê & لــدهست و بـى & 5 \\
\hline & Front and back & ber u pişt & لـابهر و يشت & 6 \\
\hline & Bosom and front & sîng u ber & آسينگ و بهر & 7 \\
\hline & Eye and eyebrow & çav u birî & لـاجاؤو برى & 8 \\
\hline
\end{tabular}

\begin{tabular}{|c|c|c|c|c|}
\hline & I and you & ez u tu & لـائهز و تو & 9 \\
\hline & Male and female & nêr u mê & لـانير و مىّ" & 10 \\
\hline & Bride and groom & bwîk u zava & لــــــك و زاثا & 11 \\
\hline & Wife and husband & jin u mêr & لـازّن و ميّر & 12 \\
\hline \multirow[t]{13}{*}{ Parents } & Mother and father & deyk u bab & لــدهيك و باب & 13 \\
\hline & $\begin{array}{l}\text { Uncle and nephews - } \\
\text { Nieces }\end{array}$ & xal u xwarza & لـ لخال و خوارزا & 14 \\
\hline & $\begin{array}{l}\text { Uncle and nephews - } \\
\text { Nieces }\end{array}$ & mam u braza & [ـامام و برازا & 15 \\
\hline & Mother and daughter & deyk u kiç & |لـدهيك و كج & 16 \\
\hline & Father and son & bab u kur & [إباب و كور & 17 \\
\hline & Sister and brother & xwîşk u bira & لـاخويشك و برا & 18 \\
\hline & Small and big & biçîk u mezin & لـ لـبجيك و مهزن & 19 \\
\hline & Drum and clarinet & dehol u zirna & | لـدههول و زرنا & 20 \\
\hline & Black and white & reş u spî & لـــرهش و سبى & 21 \\
\hline & Affection and love & èşq u viyan & لــاعهشق و ثيان & 22 \\
\hline & Physique & bejin u bal & لـابـزن و بال & 23 \\
\hline & Snow and rain & befir u baran & لـابهفر و باران & 24 \\
\hline & Mouth and lip & dev u lêv & لــــدهو و ليّف & 25 \\
\hline \multirow[t]{3}{*}{ Faithfulness } & Bread and salt & nan u xwê & لــان و خويى & 26 \\
\hline & Short and tall & kurt u dirêj & لـاكورت و دريَّز & 27 \\
\hline & Death and life & mirin u jiyan & لـــــرن و زيان & 28 \\
\hline $\begin{array}{l}\text { Dice game, } \\
\text { Behave randomly }\end{array}$ & Six and five & eş u bêşş & لـشهش و بيّش & 29 \\
\hline \multirow[t]{7}{*}{ Organized, neat } & Way & rêk u pêk & لـاريكك و بيّك & 30 \\
\hline & Unstick and askew & sist u xar & لـــــت و خوار & 31 \\
\hline & trees & dar u bar & لـــار و بار & 32 \\
\hline & Poppies & helal u beybîn & 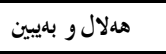 & 33 \\
\hline & Left and right & ep u rastç & لـ إجهب و راست & 34 \\
\hline & Ground and sky & èrd u esman & لـــــرد و ئدسمان & 35 \\
\hline & Concern and depression & xem u kuvan & آنهم و كوثان & 36 \\
\hline
\end{tabular}


Journal of University of Duhok., Vol. 20, No.2 (Humanities. and Social. Sciences), Pp76-93, 2017

DOI: https://doi.org/10.26682/hjuod.2017.20.2.7

\begin{tabular}{|c|c|c|c|c|}
\hline & Groan and regret & axu of & لـأناخ و ئوف & 37 \\
\hline Sense of Sadness & $\begin{array}{l}\text { Inflammation and } \\
\text { depression }\end{array}$ & kul u kuvan & إكول و كوقان & 38 \\
\hline \multirow[t]{7}{*}{ Sense of Laziness } & Motionless & sist u pist & ل][سست و بست & 39 \\
\hline & Exigencies & kel u pel & 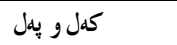 & 40 \\
\hline & Old and new & kevn u nwî & إكهفن و نوى & 41 \\
\hline & Luck and sustenance & rizq u nesîb & لـارزق و نهصيب & 42 \\
\hline & Sound and color & deng u reng & 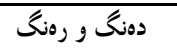 & 43 \\
\hline & Boughs & eq u meqç & لـ إجهق و مدق & 44 \\
\hline & Hastiness & lez u bez & ل & 45 \\
\hline Simple Things & Things & xir u mir & لـ لاخر و مر & 46 \\
\hline Place of Residence & House and survival & xan u man & إنان و مان & 47 \\
\hline Real Estates & House and front & xan u ber & لـانـان و بهر & 48 \\
\hline \multirow[t]{2}{*}{ Simple Things } & Things & tişt u mişt & [اتشت و مشت & 49 \\
\hline & Alive and healthy & sax u selîm & الساخ و سليم & 50 \\
\hline \multirow[t]{3}{*}{ Simple Things } & Boscages & 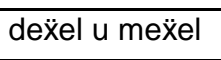 & ل] [دهغل و مdغل & 51 \\
\hline & Wheat and grain & dexl u dan & لـادهخل ودان & 52 \\
\hline & Red and white & sor u spî & لـاسور و سبى & 53 \\
\hline $\begin{array}{l}\text { Kurdish Wear } \\
\text { (Male's Wear) }\end{array}$ & Trouser and jacket & el u şepikş & لــاشهل و شهيك & 54 \\
\hline \multirow[t]{3}{*}{ Sometimes } & Times & car u bar & | إنجار وبار & 55 \\
\hline & Paths & rê u bar & لـارىّ و بار & 56 \\
\hline & Happiness and joy & keyf u xoşî & لــاكيف و خوشى & 57 \\
\hline \multirow[t]{2}{*}{ Sense of Sadness } & Inflammation and wound & kul u birîn & [اكولو برين & 58 \\
\hline & Hot and soft & germ u nerm & 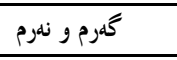 & 59 \\
\hline \multirow[t]{2}{*}{ Destiny } & Head and place & ser u şwîn & إسهر و شوين & 60 \\
\hline & Pretty & ux u şeng ş & لـاشوخ و شهنى & 61 \\
\hline Two Friends & Young Goats & zeng u beng & 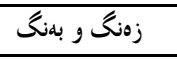 & 62 \\
\hline $\begin{array}{l}\text { Beautiful Maidens live } \\
\text { in Paradise }\end{array}$ & Houris & zerî u perî & لـ لـهرى و يهرى & 63 \\
\hline \multirow[t]{6}{*}{ Traffic } & Coming and going & hatin u çun & لــاتن و يجوون & 64 \\
\hline & Farm and sheep & rez u pez & (لمارهز و بهز & 65 \\
\hline & Obsequies & n u tazîşî & لـآشين و تازى & 66 \\
\hline & Wish and hope & hîvî u omêd & الـهيفى و ئوميّد & 67 \\
\hline & Goose and pike & qaz u quling & لـاقز و قولنگ & 68 \\
\hline & Plain and resort & deşt u zuzan & لـــــت و زوزان & 69 \\
\hline \multirow[t]{3}{*}{ Diaries } & $\begin{array}{l}\text { Variety of Cheese and } \\
\text { cheese }\end{array}$ & jajî u penîr & لـأرازى و يدنير & 70 \\
\hline & Bread and yogurt & nan u mast & لـانان و ماست & 71 \\
\hline & Cold and hot & sar u germ & إسار و گهرم & 72 \\
\hline \multirow[t]{3}{*}{ News } & Sound and subject & deng u bas & [ــــــ و وباس & 73 \\
\hline & Crazy and naughty & dîn u har & إدين و هار & 74 \\
\hline & Curvature & xar u vîç & إخار و فيَج & 75 \\
\hline \multirow[t]{4}{*}{ Neighbors } & Door and neighbors & der u cîran & لــــهر و جيران & 76 \\
\hline & Disease and drug & derd u derman & لـدهرد و دمرمان & 77 \\
\hline & $\begin{array}{l}\text { Milkmaid and } \\
\text { shepherded }\end{array}$ & bêrî u şivan & [] [بيرى و شفان & 78 \\
\hline & Cold and chilly & sir u seqem & لـاسلـر و سهقدم & 79 \\
\hline
\end{tabular}


Journal of University of Duhok., Vol. 20, No.2 (Humanities. and Social. Sciences), Pp76-93, 2017

DOI: https://doi.org/10.26682/hjuod.2017.20.2.7

\begin{tabular}{|c|c|c|c|c|}
\hline & Foodstuff & qît u mît & إلقت و ميت & 80 \\
\hline & Scraps & qaf u qut & لـ لـقاف و قوت & 81 \\
\hline & Trench and pit & kend u kur & [إكهند و كور & 82 \\
\hline \multirow{2}{*}{$\begin{array}{l}\text { Group of Friends or } \\
\text { people }\end{array}$} & Group & şil u mil & لـالشل و مل & 83 \\
\hline & Tricks & senî u menî & ] [سلىنى و مهنى & 84 \\
\hline \multirow[t]{3}{*}{ Liar } & Fart and lie & tir u vir & لاتتر و ثر & 85 \\
\hline & Heart and liver & dil u mêlak & إدـل و ميّلاكاك & 86 \\
\hline & Heart and soul & dil u can & لـادل و جان & 87 \\
\hline \multirow[t]{7}{*}{$\begin{array}{l}\text { One works free: no } \\
\text { payment }\end{array}$} & Bread and abdomen & nan u zik & لــان و زك & 88 \\
\hline & Meadow and garden & mêrg u çîmen & لـــيرّ و وجيمهن & 89 \\
\hline & Friend and companion & heval u hogir & 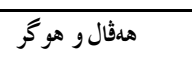 & 90 \\
\hline & Wind & hir u ba & لـاهر و با & 91 \\
\hline & Lentil and chickpea & nîsk u nok & لــنيسك و نوك & 92 \\
\hline & Curves & çep u çîr & 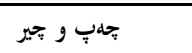 & 93 \\
\hline & Soft & nerm u nol & لـالنهرم و نول & 94 \\
\hline Simple Things & Very ting things & hîr u mîr & لـهير و مير & 95 \\
\hline \multirow[t]{6}{*}{ Sewing } & String and needle & dezî u derzîk & لـ & 96 \\
\hline & Cracks & şeq u peq & لـالشهق و يدق & 97 \\
\hline & Fear and flutter & tirs u lerz & لـاتوس و لهرز & 98 \\
\hline & Condition and terms & hel u merc & إلهدل و مهرج & 99 \\
\hline & Turnip and beet & şêlim u şilindir & آـشيّلم و شلندر & 100 \\
\hline & Here and there & vêrê u wêrê & 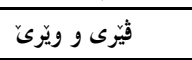 & 101 \\
\hline Kurdish Lady's gown & Frock & kiras u fîstan & لـكراس و فيستان & 102 \\
\hline \multirow[t]{4}{*}{$\begin{array}{l}\text { Kurdish wear } \\
\text { (Male's wear) }\end{array}$} & Hat and headband & kulav u dersuk & لـاكو لاثو ودرسوك & 103 \\
\hline & Clothes & cil u berg & ][]جل و بمرى & 104 \\
\hline & Spring and river & kanî u rîbar & [اكانى ورييار & 105 \\
\hline & $\begin{array}{l}\text { Cardamom and } \\
\text { cinnamon }\end{array}$ & hêl u darçîn & لهـيّل و دارجين & 106 \\
\hline \multirow[t]{9}{*}{24 Hours } & Night and day & şev u roj & لــلشهُو وروز & 107 \\
\hline & Gold and silver & zêr u zîv & لـازيرّر و زيڤ & 108 \\
\hline & Cattle & terş u tewal & لـتهدش و تلهوال & 109 \\
\hline & Eat and drink & bixu u vexu & 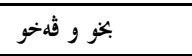 & 110 \\
\hline & Liver and bowel & cerg u hinav & آـهمرگ و هناؤ & 111 \\
\hline & Path and bridge & rêk u pir & الميتك و ير & 112 \\
\hline & Bedrock & berd u binä̈e & لـإبهرد وبناغه & 113 \\
\hline & Discussion & gift u go & 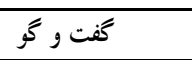 & 114 \\
\hline & Debate & dan u standin & لـ[ــان و ستاندن & 115 \\
\hline \multirow[t]{2}{*}{ Compulsory } & Want and does not want & bivêt u nevêt & إبقيُّت و ندقيُّت & 116 \\
\hline & Sour and spiced & tirş u tîj & لماترش و تيز & 117 \\
\hline \multirow[t]{3}{*}{ Foolish } & Donkey and bullock & ker u gulik & |كلكهر و گولك & 118 \\
\hline & Flower and narcissus & gol u nêrgiz & |كاتول و نيّزگز & 119 \\
\hline & Foundations & dam u dezgeh & لـإدام و دهز گهه & 120 \\
\hline \multirow[t]{2}{*}{ Relatives } & Person and work & kes u kar & [اكس و كار & 121 \\
\hline & Charity and evil & xêr u şer & ل الذيّز و شهر & 122 \\
\hline Insects & Flies & mêş u mur & لميش و مور & 123 \\
\hline
\end{tabular}




\begin{tabular}{|c|c|c|c|c|}
\hline Kurdish Epic & $\begin{array}{l}\text { Person's name and } \\
\text { Person's name }\end{array}$ & mem u zîn & لـــمه و زين & 124 \\
\hline & Climbing and descending & jêhel u jurda & 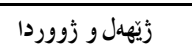 & 125 \\
\hline \multirow[t]{4}{*}{ Authentication } & Straight and right & rast $u$ dirust & لـاراست و دروست & 126 \\
\hline & Wet and dry & teŕ u hişk & لـاتهر و هشك & 127 \\
\hline & Sadness and imagination & xem u xiyal & لـ اخهم و خيال & 128 \\
\hline & Charity and joy & xêr u xoşî & لـخيّر و خوشى & 129 \\
\hline Kurdish Epic & $\begin{array}{l}\text { Person's name and } \\
\text { Person's name }\end{array}$ & mem u zîn & آلـمهم و زين & 130 \\
\hline Kurdish Epic & $\begin{array}{l}\text { Person's name and } \\
\text { Person's name }\end{array}$ & şirîn u ferhad & لـشرين و فرهاد & 131 \\
\hline Kurdish Epic & $\begin{array}{l}\text { Person's name and } \\
\text { Person's name }\end{array}$ & xec u siyabend & لـخهج و سيابلند & 132 \\
\hline \multirow[t]{2}{*}{ Kurdish Epic } & $\begin{array}{l}\text { Person's name and } \\
\text { Person's name }\end{array}$ & leyl u mecrîm & لـلديل و مهجريم & 133 \\
\hline & God and prophet & xodê u pêxember & 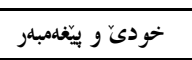 & 134 \\
\hline Food meal & Rice and soup & birinc u avik & لـابرنج و ئاثك & 135 \\
\hline \multirow[t]{3}{*}{ Possessions } & Circumstance and house & al u malh & إ] ال و مال & 136 \\
\hline & Little and much & kêm u zêde & لـ اكيّم و زيّده & 137 \\
\hline & Beard and mustache & rîh u simbêl & الـاريه و سبييّل & 138 \\
\hline \multirow[t]{4}{*}{$\begin{array}{l}\mathrm{VIP} \\
\end{array}$} & $\begin{array}{l}\text { White Beard and } \\
\text { handsome }\end{array}$ & rîh spî u maqîl & لـاريه سبيى و ماقيل & 139 \\
\hline & Someone & filan u bêvan & [ـفلان و بيثڤان & 140 \\
\hline & Fast and prayer & rojî u nivêj & لـاروزى و نفيزّة & 141 \\
\hline & Origin and tribe & esl u îcax & لـائهسل و ئيجاخ & 142 \\
\hline \multirow[t]{10}{*}{ Agriculture } & General and old & gist u kal & إكت و كال & 143 \\
\hline & Travel and tourism & geşt u gozar & [إكهت و كوزار & 144 \\
\hline & Flower and rose & gol u golzar & لـاكول و زولزار & 145 \\
\hline & Saying and lesson & gut $u$ bend & لـكوت و بهند & 146 \\
\hline & Fear and hunger & tirs $\mathrm{u}$ birs & لـترس و برس & 147 \\
\hline & Deficiencies & kêm u kasî & [اكيّم و كاسى & 148 \\
\hline & $\begin{array}{l}\text { Mother in law and father } \\
\text { in law }\end{array}$ & xesî u xezîr & لـخهى و خهزير & 149 \\
\hline & $\begin{array}{l}\text { Village's name and } \\
\text { village's name }\end{array}$ & sîyar u spîndar & ][سيار و سبيندار & 150 \\
\hline & $\begin{array}{l}\text { Village's name and } \\
\text { village's name }\end{array}$ & bank u eriz & لـابانك وئدرز & 151 \\
\hline & $\begin{array}{l}\text { Village's name and } \\
\text { village's name }\end{array}$ & nêrwe u rêkan & ]ـنيزّوه و ريكان & 152 \\
\hline \multirow[t]{2}{*}{$\begin{array}{l}\text { Abdomen and } \\
\text { Sexual Satisfaction }\end{array}$} & $\begin{array}{l}\text { Abdomen and lower part } \\
\text { of abdomen }\end{array}$ & zik u bin zik & لـازك و بن زك & 153 \\
\hline & Soul & rih u can & لـارحو جان & 154 \\
\hline Simple things & Things & xirxirk u mirmirk & لـخرخرك و مرمرك & 155 \\
\hline Simple things & Things & pirpirk u mirmirk & ]ـ[بريرك و مرمرك & 156 \\
\hline Kurdish food & Bowels & ėrik u rîvîk & لــاكيرك و ريثيك & 157 \\
\hline \multirow[t]{3}{*}{ Simple things } & Small Parts & pirt u mirt & ل]يرت و مرت & 158 \\
\hline & Finger and foot & til u pê & لـاتل و بيى" & 159 \\
\hline & Valleys & dol u nihal & [ـادول و نهال & 160 \\
\hline Noise & Slap and sound & şeq u dûq & لـاشهق و دووق & 161 \\
\hline Noise & Slap and solid & şeq u req & 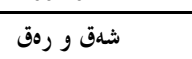 & 162 \\
\hline Beating & Slap and kick & şeq u pên & لـالشقق و بينين & 163 \\
\hline
\end{tabular}




\begin{tabular}{|c|c|c|c|c|}
\hline Environment & Around and near & dewr u ber & ل الـدور و بهر & $\overline{164}$ \\
\hline & Laughing & tîq u lîq & لـتيق و ليق & 165 \\
\hline \multirow[t]{4}{*}{ Simple things } & Small Parts & qîç u mîç & لــقيجّ و ميجيج & 166 \\
\hline & Naked & rîs u çîmlaq & إلريس و جيملاق & 167 \\
\hline & Nut and almond & gîz u bahîv & |كيز و باهيف & 168 \\
\hline & Survival and annihilation & man u neman & لــامان و نهمان & 169 \\
\hline $\begin{array}{l}\text { Sound of Breaking } \\
\text { such as Thunder }\end{array}$ & Sound & irîq u pirîqş & لـ إشريق و يريق & 170 \\
\hline \multirow[t]{13}{*}{ Accurate } & Meter and exact & fît u fîtlan & |لفيت و فيتلان & 171 \\
\hline & Tone and poetry & awaz u hozan & [لـأواز و هوزان & 172 \\
\hline & Leg and calf & ling u pîq & لـالنگ و بيق & 173 \\
\hline & Garlic and onion & sîr u pîvaz & لـاسير و بيثاز & 174 \\
\hline & Flexible and resilient & nerm u helîm & لـانهرم و حلديم & 175 \\
\hline & Respect and greeting & rêz u silav & إلـيزّ وسلاثة & 176 \\
\hline & Buying and selling & kirîn u firotin & لــاكرين و فروتن & 177 \\
\hline & Looker and listener & bîner u gohdar & ] [بينهر و گؤهدار & 178 \\
\hline & Rider and walker & sîyar u peya & لـالسيار و بيديا & 179 \\
\hline & Grinding and plough & distar u hevcar & إدستار و هدفُجار & 180 \\
\hline & Sieve & moxil u bêjîng & 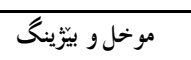 & 181 \\
\hline & Tobacco and pipe & tîtin u qelîn & لـتيتن و قلين & 182 \\
\hline & Lance and bow & tîr u kivan & ] التير و كثان & 183 \\
\hline \multirow[t]{4}{*}{ Condition } & Hand and wood & dest u dar & 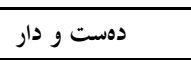 & 184 \\
\hline & Scattered & teŕa u bera & التهرا و بهرا & 185 \\
\hline & Plain and mountain & deşt u çiya & لـدهدشت و جيا & 186 \\
\hline & $\begin{array}{l}\text { Tillage Steering and } \\
\text { plough }\end{array}$ & nîrik u hevcar & لــنيرك و هدقُجار & 187 \\
\hline \multirow{7}{*}{$\begin{array}{l}\text { (Kurdish game), } \\
\text { Tombstone }\end{array}$} & Stones & kêl u bêl & إكيّل و بيّل & 188 \\
\hline & Spear and skewer & tîr u bist & لـاتير و بست & 189 \\
\hline & Wind and storm & ba u barov & لــابـا وباروة & 190 \\
\hline & $\begin{array}{l}\text { Obsequies and } \\
\text { happiness }\end{array}$ & Şîn u şadî & لـاشين وشادى & 191 \\
\hline & Hatred & kerb u kîn & لــاكهرب و كين & 192 \\
\hline & Father and grandfather & bab u kal & لـاباب و كال & 193 \\
\hline & Plait & kezî u bisk & [اكهزى و بسك & 194 \\
\hline \multirow[t]{5}{*}{ Running of Time } & Time and rotation & dem u dewran & لـادهم و دهوران & 195 \\
\hline & Ornamenting and scarf & xeml u xêl & لـآخمل و خيّل & 196 \\
\hline & Meadow and garden & Mêrg u bä̈ & 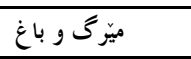 & 197 \\
\hline & Iris and spike of a grain & susin u sunbil & إسوسن و سونبل & 198 \\
\hline & Poverty & jar u jwîrî & لـآذار و زويرى & 199 \\
\hline North andSouth & Up and down & jêr u jor & ل & 200 \\
\hline \multirow[t]{7}{*}{ Sense of harshness } & Bear and monster & hirç u hov & 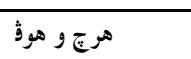 & 201 \\
\hline & Wind and rain & ba u baran & الـابا و باران & 202 \\
\hline & Thicket and thorn & deh̉l u dirî & ]ــدهل و درى & 203 \\
\hline & Flower and grass & gol u giya & المولو زيا & 204 \\
\hline & Charity & Xêr u bêr & 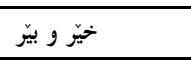 & 205 \\
\hline & Pipe & bask u qelîn & |لـاباسك و قدلين & 206 \\
\hline & Pain and cramp & êş u jan & لـأئش و ران & 207 \\
\hline
\end{tabular}




\begin{tabular}{|c|c|c|c|c|}
\hline & Guesthouse & kuçik u dîwan & ][كو جلك و ديوان & 208 \\
\hline & Servants & xulam u xidam & لــاخولام و خدام & 209 \\
\hline \multirow[t]{11}{*}{ Confusion } & Fog & mij u moran & ل المثز وموران & 210 \\
\hline & Mountain & çel u çiya & إجهل و جيا & 211 \\
\hline & Dancing & govend u dîlan & 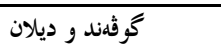 & 212 \\
\hline & Problems & gîr u girift & |كير و كرفت & 213 \\
\hline & Go and come & here $u$ were & إلههره و وصره & 214 \\
\hline & Month and year & heyv u sal & لــالههيف وسال & 215 \\
\hline & Saturday and Sunday & şembî u êkşemb & لـاشمبى و ئيكك شهمب & 216 \\
\hline & Meat and blood & goşt u xwîn & لـاكوشت و خوين & 217 \\
\hline & Aged and grandfather & pîr u kal & إبير و كال & 218 \\
\hline & Come and doesn't Come & hat u nehat & لــات و نهات & 219 \\
\hline & Money and stamp & pare u pul & إياره و يول & 220 \\
\hline \multirow{3}{*}{ Flumes } & Water and pipes & av u sulîn & لـأثأو سولين & 221 \\
\hline & Gold and adornment & zêr u zînet & لـ لـيّر و زينهت & 222 \\
\hline & Concerns & xem u xefet & لـاخهم و خدفهت & 223 \\
\hline \multirow[t]{8}{*}{ Confusion } & Roily & Şêl u bêl & 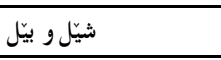 & 224 \\
\hline & Stand up and sit down & rabe u rîne & ل الرابه و رينه & 225 \\
\hline & Ate and drank & xar u vexar & آخار و ثهخار & 226 \\
\hline & Morning and evening & spêde u êvar & 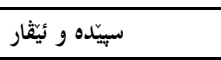 & 227 \\
\hline & This and the other & eve u yadî & الـأثة و يادى & 228 \\
\hline & Coming and going & dihêt u diçît & لــدهيت و دجيت & 229 \\
\hline & Bread and tea & nan u ça & ] لـنان و جا & 230 \\
\hline & Bread and onion & nan u pîvaz & لـانان وبيثاز & 231 \\
\hline \multirow[t]{3}{*}{ East andWest } & Sunrise and sunset & rojhelat u rojava & لـاروزههلات و روزئياًا & 232 \\
\hline & Right and wrong & heq u nehieq & 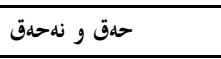 & 233 \\
\hline & Halal and taboo & hंelal u heram & لـ اسلال و حهرام & 234 \\
\hline Trees & Woods & dar u drext & لــار و درهخت & 235 \\
\hline \multirow[t]{3}{*}{ Sense of Sorriness } & Regrets & heyf u mixabin & [إحهيف و مخابن & 236 \\
\hline & Free of charges & belaş u èelaş & إبهلاش و عهلاش & 237 \\
\hline & Blame and complain & gil u gazinde & | & 238 \\
\hline \multirow[t]{5}{*}{$\begin{array}{l}\text { Rashness } \\
\text { (Adventure) }\end{array}$} & Came & hat u bat & ل الهات و بات & 239 \\
\hline & Work & ul u karş & لـالشولو كار & 240 \\
\hline & Short and fat & qut u qelew & 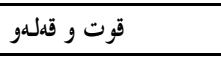 & 241 \\
\hline & Slim and tall & zeèiff u drêj & ] [ازهعيف و دريزّ & 242 \\
\hline & Poor and needy & hejar u belingaz & 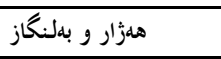 & 243 \\
\hline \multirow[t]{2}{*}{ Affairs } & Work and state & kar u bar & ل إكار و بار & 244 \\
\hline & Far and long & dîr u drêj & لــدير و دريّز & 245 \\
\hline \multirow[t]{4}{*}{$\begin{array}{l}\text { Repeating the } \\
\text { narration of actions }\end{array}$} & Chewing & cît u vecît & لـاجيت و قهجيت & 246 \\
\hline & Thud & ing u dingh & 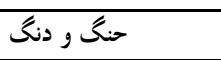 & 247 \\
\hline & Patience & sebir u hedar & لـاسببر و هددار & 248 \\
\hline & House and property & mal u mulik & ] [مال و مولك & 249 \\
\hline \multirow[t]{3}{*}{ Activity } & Active & bizav u çalak & لـابز أو و جالاك & 250 \\
\hline & Honey and cream & hingivîn u qeymä̈ & 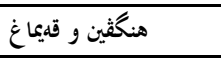 & 251 \\
\hline & Sugar and salt & şekir u xwê & 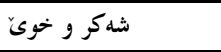 & 252 \\
\hline
\end{tabular}




\begin{tabular}{|c|c|c|c|c|}
\hline Construction Items & Iron and cement & asin u çîmento & لــائاسن وجيمهنتو & 253 \\
\hline \multirow[t]{8}{*}{$\begin{array}{l}\text { Sense of } \\
\text { Deceptiveness }\end{array}$} & Cheating & hîil u hewale & لـاحيل و حهواله & 254 \\
\hline & Surface and implied & serve u binve & [اسمهرثه و بنثه & 255 \\
\hline & Washing & şîştin u veşiştn & الشيشتن و قلششيشتن & 256 \\
\hline & Foods and drinks & xarin u vexarin & ] لخارن وقهنخارن & 257 \\
\hline & Color and cheek & reng u rî & لـارهنى ورى & 258 \\
\hline & String and lute & têl u tembîr & لـتئل و تهمبير & 259 \\
\hline & Neck and back & sto u navmil & لـ الستو و ناثمل & 260 \\
\hline & Rooster and hen & dîkil u mirîş̧ & لــديكل و مريشك & 261 \\
\hline \multirow[t]{2}{*}{ Erbil City } & Castle and beacon & qela u minare & 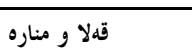 & 262 \\
\hline & Snake and scorpion & mar u dîpişk & لـارمار و ديشك & 263 \\
\hline
\end{tabular}

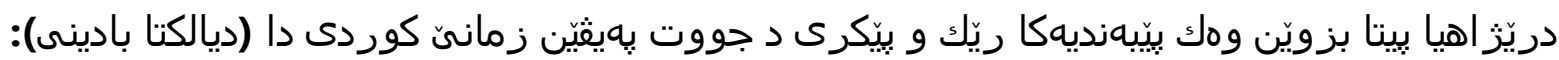
شروقهكرنها جهندى جون

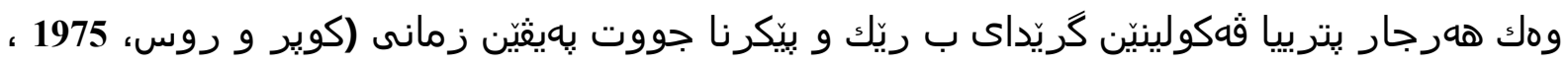

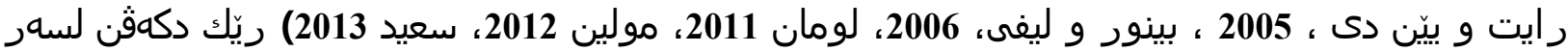

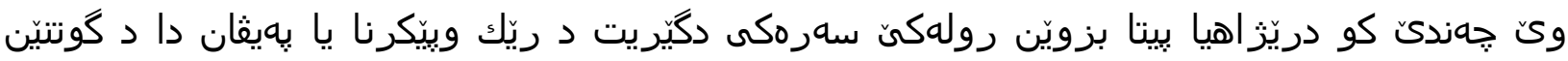

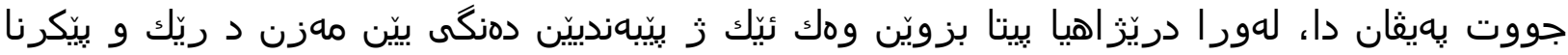

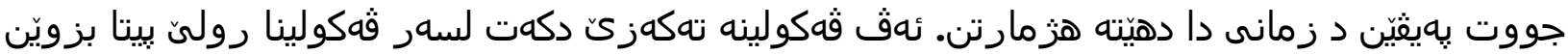

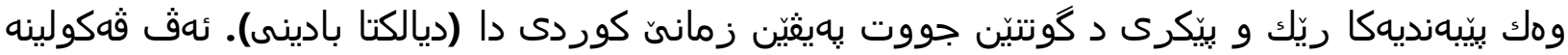

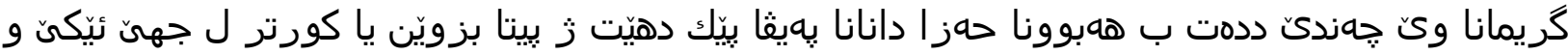

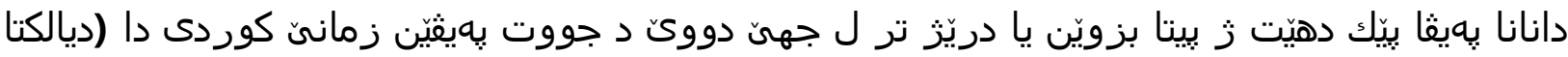

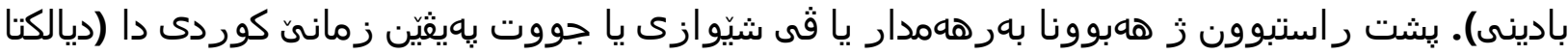

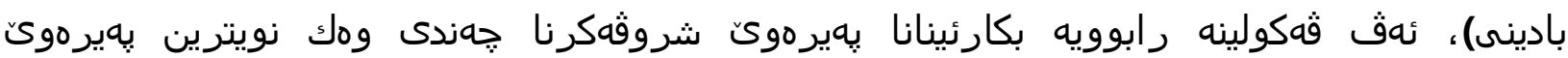

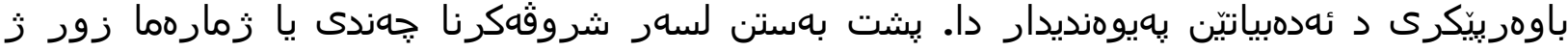

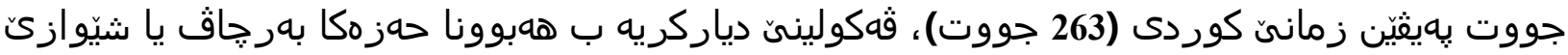

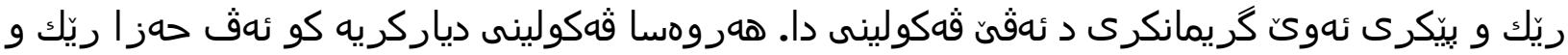

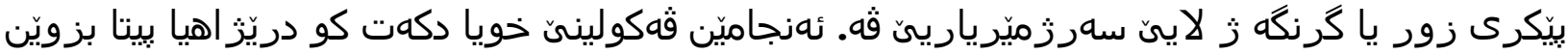

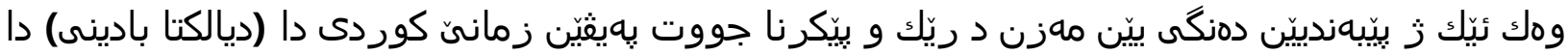

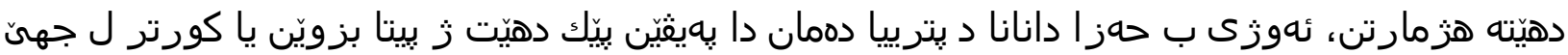

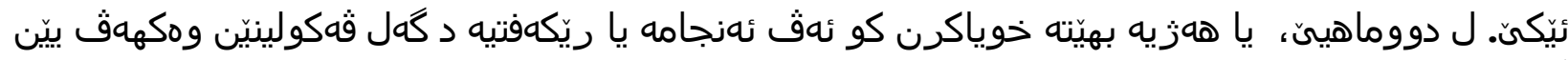

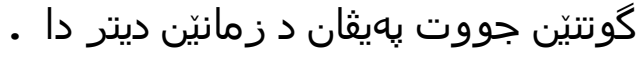

طول حرف العلة كتقييد ترتيبي في ثنائيات اللغة الكردية (اللهجة البادينية): تحليل كمي 


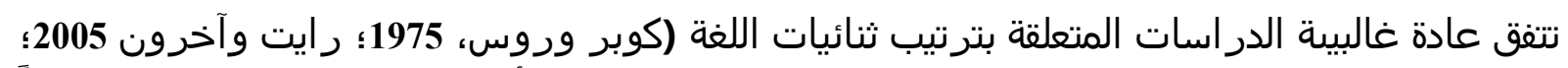

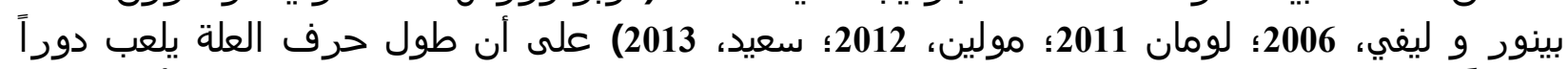

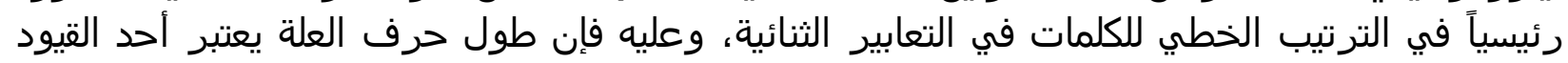

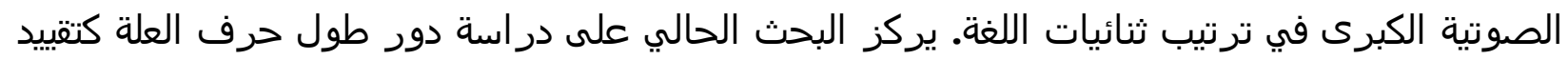

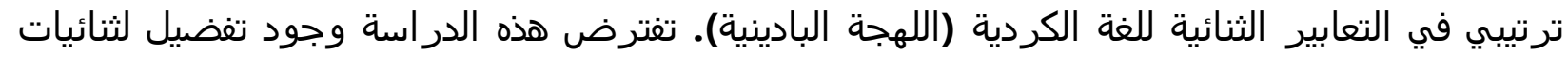

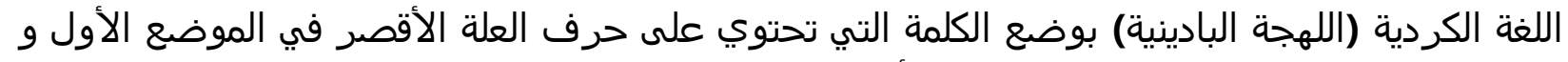

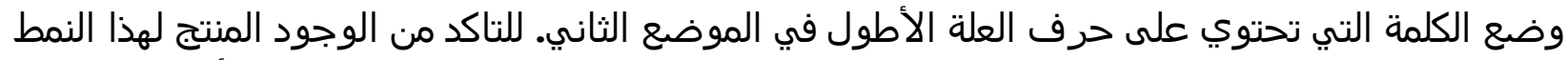

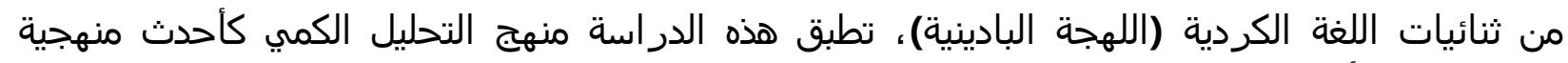

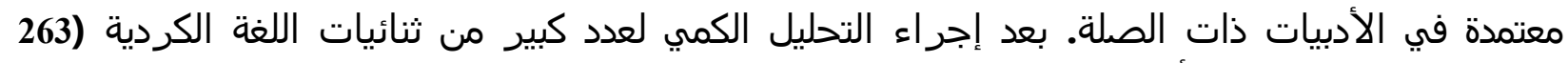

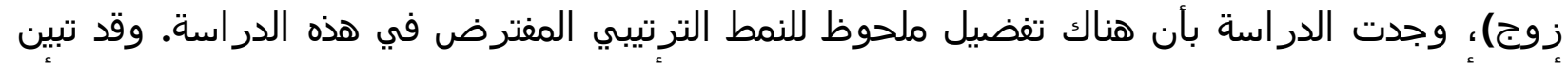

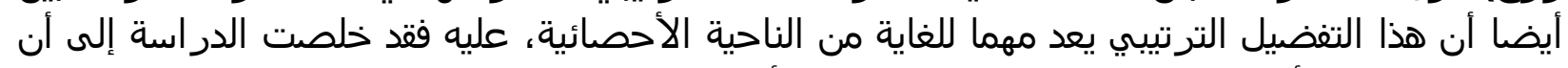

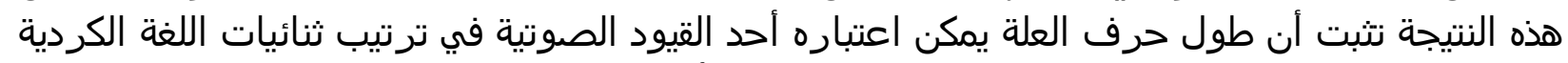

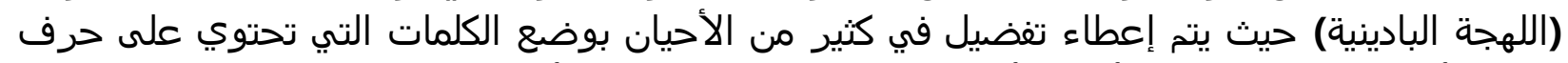

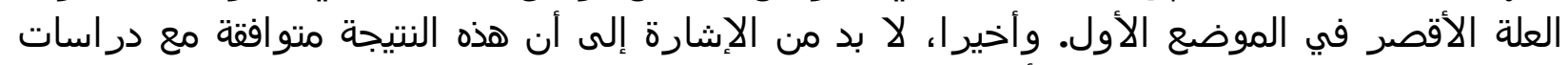
مماثلة عن التعابير الثنائية في لغات أخرى. 